thought of introducing the work into school use on the strength of one or two hastily written commendations of it, will be induced in consequence of what we have written, to examine the work for himself. We feel confident that any competent geometer who opens the book at almost any page, will endorse our criticisms, and say "the half was not told." In brief, the definitions are faulty, the enunciations are faulty, the proofs are faulty, and the typography is faulty ; if these things do not make a bad book we do not know what does. The defence is, "if the enunciations are loosely and inelegantly worded, Amiot must bear the blame which attaches in a greater degree to our trans. lations of Euclid." Alas! poor Amiot! this is an unkind cut, Mr. Morell!

R. TUCKER March 6

\section{Bullfinches and Primroses}

I HAVE a bullfinch which was hatched last summer after primroses were over. They were therefore quite new to him when I offered him the first I could get this season. He pulled it to pieces quite indiscriminately, biting stalk, flower, or calyx quite indifferently, and the same with a few more which were given to him at the same time. But since then he has often had a few at a time, perhaps twenty or thirty in all, and he now almost always bites out the lower part of the calyx, as described in NATURE, vol. ix. p. 482. Sometimes he bites a little too high up, but almost instantly tries again with better success. When that part is eaten he attacks the stalk rather than the corolla.

Last spring I offered primroses to four bullinches belonging to friends. Not one seemed to pull the flower to pieces accordins to any method. Two of them I saw only once. Another (an old bird and somewhat shy), after keing supplied with the flowers for several days, seemed as unskilful in picking out the tit bit as he was at first. The fourth was a young bird. His mistress was called away before she had heard what was the peculiarity for which I was watching. A few days later she told me she had been giving him primroses in the meantime, and had nuticed that he ate only the green part. In those few days he had learnt the art of primrose eating, not indeed quite perfectly, but wonderfully well considering how little practice he had had. C. A.M.

\section{Seasonai Order in Colour of Flowers}

Ir seems that Mr. Thiselton Dyer has thought fit to conclude the different observations made on this interesting subject by copying a part of Sachs's "Text-book." He will, I hope, allow me to point out to him the latest researches respecting the influence of light on the colour of flowers, published by $\mathrm{E}$. Askenasy, in the Botanische Zeitung, 1876, Nos. I and 2. This author made experiments with several flowers which had sufficient food at their disposal, and found that some of his flowers changed their colour when placed in the dark, while it was not so with others. Therefore it cannot be said that light has no so with others. Therefore it cannot be said that author, has as yet not been explained; other experiments will have to be made to clear up this point.

I think the colour of most flowers is a thing that by continued inheritance during a very long lapse of time has become almost constant, and cannot be changed in a few weeks or almost constant, and cannot beriments with the same flowers months. Long-continued, perhaps, show more considerable changes than Askenasy found.

So much for the point referred to by Mr. Dyer.

As to the seasonal order itself, a continuation of Mr. Alexander Buchan's observations would be necessary, and probably also experiments with the several parts of the spectrum to which the flowers are to be exposed.

As this letter was written, I read that of Mr. Wm. Ackroyd (NATURE, vol. xiii., p. 366); doubtless every one will expect with great interest his following note.

J. C. COSTERUS

$$
\text { Amsterdam }
$$

\section{Plant Fertilisation}

SOME short time since I observed a rather curious case of plant fertilisation through the medium of insects, and thinkingas the subject is one which is attracting much attention from as the subject of your botanists at presecially perhaps as occurring in this remote part of the world), I take the liberty of forwarding you the particuof the world), I take the can find a corner for them in your valuable journal.
Growing rather abundantly just on the coast here is a small shrub belonging, I believe, to the sub-order Coffex, having numerous small greenish flowers, the interior of the corolla tube filled with silky white hairs, and the style bent in a peculiar manner, so as to bring it to one side of the tube. I observed the anthers delusce before the flower buds open covering the stigmatic surface (which is simply a thickened continuation of the style) with pollen. I noticed that all the individuals of this species of shrub were visited by a kind of ant in large numbers, and as soon as a flower opened they began pulling out the hairs, lining the corolla tube, and often biting off the stamens also, in order to clear a way down to the nectar contained at the bottom of the tube. In doing so they often support themselves by clinging to the pollen-covered style with their posterior legs. The bend in the style which brings it to the side of the corolla tube prevents it from being an obstruction while they are obtain ing the nectar, although, so eager are they to get it even to the last drop, that in a few old flowers I noticed even the style removed. The pollen keeps dry for a considerable time, so that cross-fertilisation is effected by the removal of pollen from the stigma of one flower to that of another.

We have here, therefore, several adaptations of structure and habit to ensure that end. The deluscence of the anthers while in the bud removes the pollen from a part of the flower where it would in all probability be wasted (when the ants bite off the anthers) to another part, where by a peculiarity in its structure, viz., the bend in the style, it is protected and transferred to other flowers. The hairs in the corolla-tube, by rendering the approach to the nectar difficult, and thus making the use of the style as a support needful, also increase the chances of crossfertilisation.

Durban, Natal, South Africa, Jan. 25

The Visibility of Mercury

Perhaps some of your readers may, like myself, have been struck with the remarkable brilliance of Mercury to the naked eye on the evening of January 26 . I scarcely ever remember to have seen the planet so well deserving the epithet $\sigma \tau\{\lambda \beta \omega \nu$. Since April, I 858 I have noticed it twenty-one times with the naked eye at its evening apparitions. It seems difficult to reconcile the liment of Copernicus that he would die without seeing Mercury with the accounts of his life. The common reason given is, that it was always enveloped, to him, amid the vapours of the Vistula. But he did not pass all his life in that part of Europe. At one time he went to Bologna and stayed with Dominic Maria, a professor of astronomy in that place. After this he proceeded to Rome, where he was made professor of mathematics, and where we find him actually engaged in making observations about the year 1500 .

The amateur may look out for Mercury near the western horizon, after sunset, about the following dates :-I877, Jan. I0, April 29; I878, April 10; 1879 , March 26 ; 1880, March 7 I881, Feb. 20; 1882, Feb. 2; r883, May 6; I884, April I8; 1885, March 31; I886, March I5.

Tycho Brahe, who could not have enjoyed a very favourable latitude for picking up the planet, gives us the following notes in his "Historia Celestis": -

I585, Nov. I5.- "Apparuit hoc tempore matutino $\Varangle$ tanquam rubricunda quædam stella secundæ magnitudinis et mediæ, quasi 2 et I magnitudinis."

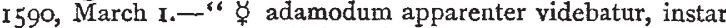
stellarum primæ magnitudinis, adeo ut eam, quæ in dextro humero Orionis est, magnitudine visibili repræsentaret. Si $\nsucceq$ diametrum visibilem feceris $21^{\prime}$, non inconvenienter se habebit."

1596, March 15.-" "Erat hâc vesperâ apprimè serenum et mediocriter tranquillum. $\quad \zeta$ hâc vesperâ satis fuit conspicuus quippe cujus quantitas stellam inter primæ et secundæ magnitudinis referebat."

Measurements of the diameter of the planet are best obtained when it is seen in transit on the sun, of which there will be a very favourable opportunity for several hours on May 6, 1878 . After this, it is doubtful whether we shall see Mercury on the sun again this century in England, as he passes off the solar disc on May ro, 189r, about half-an-hour after sunrise, and on Nov. 10, 1894, the ingress of the planet is only a few minutes before sunset. For a transit to be seen thoroughly from this country we must wait till Nov. 12, 1907, and Nov. 6, 19r4, both of which will be visible throughout here.

Upton Helions Rectory, Crediton, Feb. 2 I
SAMUEL J. JOHNSON 